\title{
算鋼筒゙して使用する「ニッケル鋼 の代用鋼に就いて
}

會員 小林子之輔

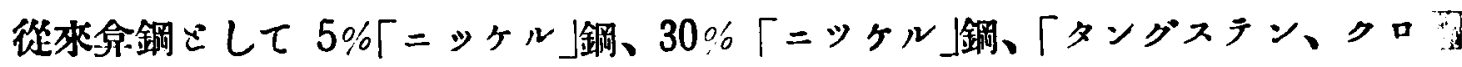
一ム」鋼、高「ニッヶル、クローム」鋼、等の順序で使用されね。上記の中で高「ニ ッケ、ルクローム鋼は理想的拿鋼であるけれごも其價頗る不廉である。而して其 の重要成分である「ニッヶル」は我國に全く虐出しない、皆外國から輸入に俟つて 居るのである。然るに「ニッヶル」を含む特殊鋼は軍器、飛行機及自働車其他諸機 械等に於て多大の需要がある。故に純本邦産の他の金盛を以て「ニッケル」に代用 せしむる研究は軍需工策上已ならす自給自足の國家的見地からしても最も緊要な るのである。因つて吾人は「ニッヶル」代用の一項目こして、拿鋼として使用する $\Gamma$ 「ケル」鋼の代用研究を行つて處安價で然も純本邦库の高炭素高「クローム」 鋼で代用せしむる事を得てのである。

抑を飛行機の栐な高速度の發動機の排氮瓦斯の温度は鋼の變態点以上に昇る事 珍れでないから拿鋼は變態点の高いものが理想である。且亦排氣瓦斯中の「ハイ ドロカーポン」等に對する抵抗性の大なるものが希望せらるつから拿銅の適否を 炏の三点で比較しやうと思ふ。

一、攝氏 800 度に於ける强度

二、酎酸及酎酸化度

三、價格

先之れが比較試驗として次の種類の鋼を慗造した。 


\begin{tabular}{|c|c|c|c|c|c|c|c|c|c|c|c|}
\hline 種 & 特 諕 & C & $\mathrm{Si}$ & $M n$ & $P$ & $S$ & $\mathrm{Ni}$ & $\mathrm{Cr}$ & W & Co & Vd \\
\hline $5 \%$ Ni steel $x$ & $5 \mathrm{~N}$ & .27 & .25 & .35 & .012 & .023 & 5.45 & - & - & - & - \\
\hline $30 \% \mathrm{Ni}$ steel $\quad x$ & $30 \mathrm{~N}$ & .16 & .18 & .49 & .012 & .021 & 30.79 & - & - & - & - \\
\hline $\mathrm{W}-\mathrm{Cr}$ steel & W C & .71 & .34 & .38 & .010 & $\operatorname{tr}$ & - & 4.12 & 19.02 & 1.0 & 0.5 \\
\hline $\mathrm{Ni}-\mathrm{Cr}-\mathrm{W}$ steel & $N C W$ & 30 & .19 & .56 & .030 & .016 & 4.53 & 1.00 & 2.44 & - & - \\
\hline High $\mathrm{Ni}-\mathrm{Cr}$ steəl $\times$ & $\mathrm{HNC}$ & .27 & 2.65 & .21 & .006 & .012 & 9.98 & 20.20 & - & - & - \\
\hline High C--Cr steel & $\mathrm{HCC}$ & 1.81 & .13 & .15 & .020 & .010 & - & 14.45 & - & - & 一 \\
\hline
\end{tabular}

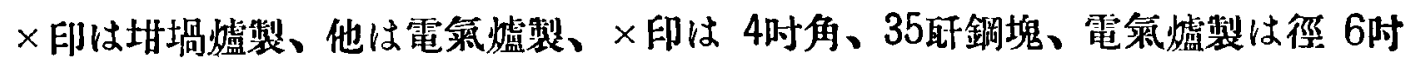
100 酉鋼塊、試驗片は上記の各鋼塊を夫々適切な温度で1吋八角長さ10吋のもの に鉣延し之れを完全に燒鈍して、高「ニッヶル、クローム」鋼已は油燒入を行つれ 試驗片の寸法は $2^{\prime \prime} \times 0.533$ 、粚引試驗機は $50.000 \mathrm{Kg}$ Riehle testing machine 在使用 した。第二表は帚引試驗の結果を示す。

第二表 張力試驗成精 比較表

\begin{tabular}{|c|c|c|c|c|c|c|c|c|c|c|}
\hline \multirow[t]{2}{*}{ 胧 } & \multirow{2}{*}{ 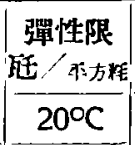 } & 抗 & \multicolumn{2}{|c|}{ 䣶/张 } & 延 & \multicolumn{2}{|c|}{ 伸 率 $\left(2^{\prime \prime}\right)$} & \multicolumn{3}{|c|}{$\begin{array}{l}\text { Merit Number } \\
\text { (抗張カメ延伸率) }\end{array}$} \\
\hline & & $20^{\circ} \mathrm{C}$ & $600^{\circ} \mathrm{C}$ & $800^{\circ} \mathrm{C}$ & $20^{\circ} \mathrm{C}$ & $600^{\circ} \mathrm{C}$ & $800^{\circ} \mathrm{C}$ & $20^{\circ} \mathrm{C}$ & $600^{\circ} \mathrm{C}$ & $800^{\circ} \mathrm{C}$ \\
\hline $5 \mathrm{~N}$ & 40.0 & 59.5 & 66.0 & - & 28.0 & 22.5 & - & 1666 & 1485 & .- \\
\hline $30 \mathrm{~N}$ & 29.0 & 58.5 & 27.0 & 12.0 & 45.0 & 24.0 & 9.5 & 2632 & 648 & 114 \\
\hline W C & 62.0 & 95.0 & 790 & 15.0 & 11.5 & 12.0 & 32.5 & 1093 & 948 & 488 \\
\hline $\mathrm{NCW}$ & 118.0 & 145.0 & 120.0 & 32.0 & 14.0 & 12.5 & 24.5 & 2030 & 1500 & 784 \\
\hline $\mathrm{HNC}$ & 70.0 & 87.0 & 51.0 & 34.6 & 37.0 & 21.5 & 13.5 & 3219 & 1097 & 467 \\
\hline $\mathrm{HCC}$ & 66.0 & 80.0 & 43.0 & 20.5 & 17.0 & 17.5 & 27.0 & 1360 & 753 & 554 \\
\hline
\end{tabular}

第三表耐酸及耐酸化試驗比較表

\begin{tabular}{|c|c|c|c|c|c|c|c|c|c|c|c|}
\hline \multirow[b]{2}{*}{ 特 號 } & \multirow{2}{*}{$\begin{array}{c}c \\
10 \% \\
\mathrm{HNO}_{3} \\
\end{array}$} & \multicolumn{2}{|c|}{ 领 } & \multirow{2}{*}{ 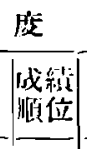 } & \multicolumn{2}{|l|}{ 五／西方制 } & \multicolumn{3}{|c|}{ 酸 化 度 瓦／本方䊓 } & \multirow[b]{2}{*}{ 總成維 } & \multirow{2}{*}{ 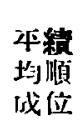 } \\
\hline & & 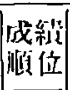 & $\begin{array}{l}10 \% \\
\mathrm{Hcl}\end{array}$ & & $\begin{array}{c}10 \% \\
\mathrm{H}_{2} \mathrm{SO}_{4}\end{array}$ & $\mid$ & $\begin{array}{c}1000^{\circ} \mathrm{C} \\
\text { 3捗間怔温 }\end{array}$ & $1000^{\circ} \mathrm{C}$ & \begin{tabular}{|l|l|} 
成縕 \\
順位
\end{tabular} & & \\
\hline $5 \mathrm{~N}$ & 0.777 & 2 & 0.0042 & 4 & 0.1423 & 6 & 0.0543 & 0.4344 & 6 & 2. 4.6 .6 & 4 \\
\hline $30 \mathrm{~N}$ & 0.316 & 4 & 0.0006 & 1 & 0.000467 & 1 & 0.0217 & 0.1735 & 2 & 4.1.1.2 & 2 \\
\hline W C & 0.836 & 5 & 0.00473 & 5 & 0.0257 & 3 & 0.0377 & 0.3016 & 5 & 5.5.3.5 & 5 \\
\hline $\mathrm{NCW}$ & 0.839 & 6 & 0.00714 & 6 & 0.1265 & 4 & 0.0346 & 0.2770 & 4 & 6.6.4. 4 & 6 \\
\hline $\mathrm{HNC}$ & 0.000917 & 1 & 0.00317 & 2 & 0.001867 & 2 & 0.00025 & 0.0020 & 1 & 1.2.2. 1 & 1 \\
\hline $\mathrm{HCC}$ & 0.799 & 3 & 0.00320 & 3 & 0.1298 & 5 & 0.0329 & 02630 & 3 & 3.35 .3 & 3 \\
\hline
\end{tabular}


第三表は耐酸及耐酸化試驗の成績である、此の試驗に用るて試片は10粍角（正

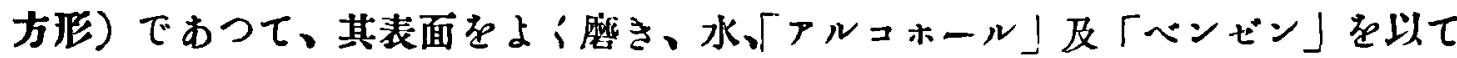

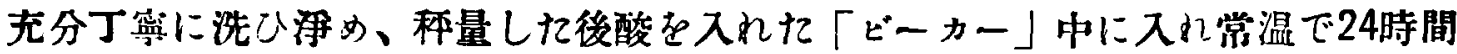
放置した。然る後「ピーカー」から取り出し水と「アルコール」とで洗ひ「デシ

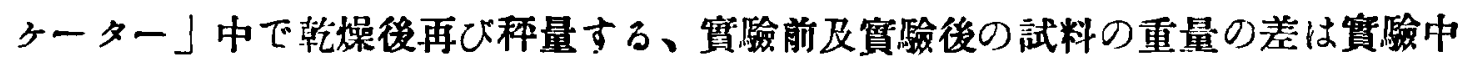
酸によつて㦄蝕された值である。此值き試料の表面積で割つけ值即ち單位面積に 於ける减量を腐蝕度とした。腐蝕度は試料表面積一本方糎上に於ける减量を瓭で 示せる值である。次に高温度の下に於ける酸化試擥では上迅の如く充分洗ひ浄め 且乾燥して試料を磁製「ボート」の中に入れて一緒に科り、次に試料を入れて睢「ボ

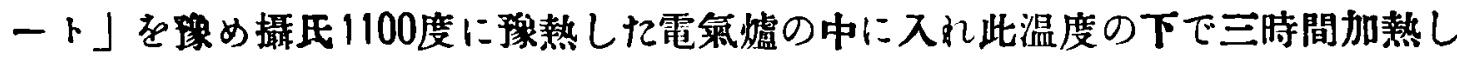

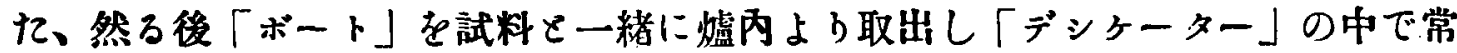
温迄冷却し再び科量しれ、而して加熱後及加熱前の重量の差は加熱中にに加はれ る酸素の重量でするから之れを試料の表面積で割れ壮單位面樍上に加はつね酸素 の重量である。之れを酸化度としれ、酸化度は試料の表面一本方糎上に加はつれ 酸素の重量を瓭で示せる值である。表中酸化度の $1000 \circ$ C 24時間恒温の值は3時 間加熱して值を換算してるのである。表中成綪順位より明かなる如く高炭素高ク ローム鋼は、高「ニッケル、クローム」鋮、高「ニッケル」銅に亞ぐ高度の無銹性を 持つて居る事が分かる。次に各銅種の單價を比較して見るこ次の順序こなる。

\begin{tabular}{|c|c|c|c|}
\hline 銅 & 俱格順位 & 圭 㴗 材 & 曤 \\
\hline $5 \% \quad \mathrm{Ni}$ steel & 6 & $\mathrm{Ni}$ & $1.700 /$ 䣶 \\
\hline $30 \% \quad \mathrm{Ni}$ steel & 3 & FeW 80\% & $1.600 /$ 䣶 \\
\hline$W$ - er steel & 1 & $\begin{array}{l}\text { High Carbon } \\
\mathrm{Fe} \mathrm{Cr} 60 \%\end{array}$ & $.380 /$ 䣶 \\
\hline $\mathrm{Nr}-\mathrm{Cr}-\mathrm{W}$ steel & 4 & $\begin{array}{c}\text { Low Carbon } \\
\mathrm{FeCr} 60 \%\end{array}$ & 1.000 /许 \\
\hline High $\mathrm{Ni}-\mathrm{Cr}$ steel & 2 & Fe Vd $40 \%$ & $15.000 /$ 䣶 \\
\hline High $\mathrm{C}-\mathrm{Cr}$ steel & 5 & Co $95 \%$ & $15.000 /$ 聒 \\
\hline
\end{tabular}

上記の如く「タングスラン、クローム」鋼、高「ニッヶル、クローム」鋼、30\%「二 ッヶル」鋼が頗る高望であつて、5\%「ニッヶル」鋼、こ高炭素高「クローム」銅は 
足格迸かに低廉である。

以上の如く高溫度に於ける强度、不銹性及び㑯格の三点を綜合するを、高炭素高 「クローム」鋼が最す優秀であるから拿龬こして充分「ニッヶル」鋼の代用こなる ものである。

終らに此の研究中始終實僵に從事せられて谷地森七郎氏に深く感謝の意を表す

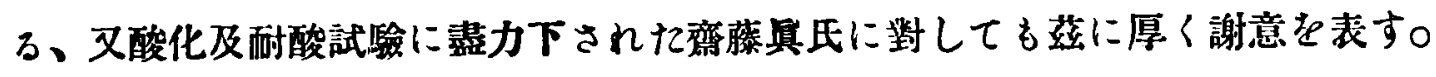

